\title{
Assessment of decomposition rate and soil nutrient status under different woody species combination in a tree plantation
}

\author{
I. O. Faboya ${ }^{1}$, S. I. Adebola ${ }^{2, *}$, O. O. Awotoye ${ }^{2}$ \\ ${ }^{1}$ Department of Forestry, Ministry of Environment Ekiti State, Ekiti State, Nigeria \\ ${ }^{2}$ Institute of Ecology and Environmental Studies, Obafemi Awolowo University, Ile-Ife, Nigeria
}

Email address:

fisrealoludare@yahoo.com (I. O. Faboya), segunawotoye@yahoo.co.uk (O. O. Awotoye), adebolasamuel@gmail.com (S. I. Adebola)

\section{To cite this article:}

I. O. Faboya, S. I. Adebola, O. O. Awotoye. Assessment of Decomposition Rate and Soil Nutrient Status under Different Woody Species Combination in a Tree Plantation. Agriculture, Forestry and Fisheries. Vol. 4, No. 2, 2015, pp. 46-54. doi: 10.11648/j.aff.20150402.14

\begin{abstract}
Forest Litter is the major input determining the nutrient accumulation within the forest soil ecosystem which goes a long way in determining forest stand productivity. To better understand this, the study investigated the litter decomposition rate and soil nutritional status under different woody species combinations in tree plantation established in 1998. Four different pocket of tree combinations Terminalia $s p$ and Tectona grandis (1); Gmelina arborea and Tectona grandis (2); Khaya sp and Tectona grandis (3); Theobroma cacao and Cola sp. (4) were used, while undisturbed natural forest served as the control. Three plots $(25 \mathrm{~m} \times 25 \mathrm{~m})$ were randomly mapped out of each site in which fresh litter were collected with litter trap (1 $\mathrm{m} \times 1$ $\mathrm{m}$ ) and 45 litter bags were placed and 90 composite soil samples to the depths of $0-15 \mathrm{~cm}$ and $15-30 \mathrm{~cm}$ collected using a stainless steel auger. These collections followed the principle of co-location in each of the plots. Litter bag technique was used for Litter decomposition rate. The results of the litter accumulation in the forest plantations were in the magnitude of Tectona grandis and Gmelina arborea $\left(1249.2 \mathrm{kgha}^{-1}\right)>$ Teak and Khaya sp. $\left(899.42 \mathrm{kgha}^{-1}\right)>$ Teak and Terminalia sp., $\left(867.58 \mathrm{kgha}^{-}\right.$ $\left.{ }^{1}\right)>$ natural forest $\left(489.96 \mathrm{kgha}^{-1}\right)$ Cocoa and Cola $\left(199.87 \mathrm{kgha}^{-1}\right)$. The decomposition rates under Tectona grandis and Khaya sp., Tectona grandis and Gmelina arborea mixtures were higher than other tree species mixtures. The rate of decomposition under Tectona grandis and Gmelina arborea mixtures was 5.3 times higher than that of Tectona grandis and Terminalia sp., Cocoa and Cola combinations and natural forest at 6 weeks. At $15-30 \mathrm{~cm}$ soil depth, the $\mathrm{C} / \mathrm{N}$ ratio was in the magnitude of Tectona grandis and Gmelina arborea $(8.6: 1)<$ Cocoa and Cola (9.3:1) < Tectona grandis and Khaya sp. (9.8:1) < Tectona grandis and Terminalia $s p$. Natural forest (11.7:1). The organic carbon and available nitrogen at $0-15 \mathrm{~cm}$ soil depth under Tectona grandis and Khaya sp. combinations were significantly lower compared with other trees species combinations. However, the available phosphorus was significantly higher under Tectona grandis and Terminalia sp. compared with other tree species combinations. The dendograme indicated that the soil characteristics in the various tree species combinations plot were similar up to $50 \%$ with four clusters. The observed relative nutrient availability within the structurally different forested ecosystem in the study area might not be unconnected to the litter mixtures emerging from different tree combinations.
\end{abstract}

Keywords: Tree Species Combinations, Litter Decomposition, Plantation Forestry, Natural Forest, Soil Nutrient Status

\section{Introduction}

The replacement of native forests by exotic tree plantations can cause important changes in diversity and community composition at local and regional scales (Brockerhoff et al., 2001). Forest leaves through photosynthesis absorb and retain nutrients in foliage and through abscission follow by decomposition return the nutrient into the ecosystem. Nutrient cycling is clearly related to decomposition and the availability of nutrients in any given soil is due in large part to the decay dynamics of the organic matter in that soil (Berg and McClaugherty, 2008). Forest litter is the dominant input of organic matter in the forest ecosystem and its' decomposition represent major pathway through which nutrient is being released into the environment.

The amount of organic matter present within the system is controlled by the relative rates of litter accumulation and loss (Baldock et al., 2004). Decomposition of leaf and needle litter is critical to forest nutrient cycling (Cadisch and Giller 1997). The success of tree species mixture in a plantation has 
been based primarily on those species with complimentary characteristics such as growth rate variation, crown structure, foliar phenology and root depth (Forrester et al., 2004). Variation in this characteristic among these species may result in efficient biomass production and at the same time maintain a nutrient balance in the ecosystem. Rothe and Binkley (2001) noted that quantity and quality of litter fall in forest ecosystem are primarily based on stand species composition. Ola Adams, (1978) and Okeke and Omaliko, (1992) also reported that litter decomposition depends on the species in the forest or the composition of the plantation. Exotic species could be used as catalyst for secondary growth in mixed plantations (Parrota, 1992). There are strong concerns that the conversion of tropical forests into land for agriculture or plantation has negative effects on the carbon budget (Hertel et al., 2009). This implies that the conversion of natural forest to mono specific or mixed plantation could not but have its impact on the ecosystem. Singh et al. (1985) in their studies on changes in soil properties under different plantations reported that there are alterations in the number of soil chemical properties such as lower $\mathrm{pH}$ and increased nutrient availability.

Various studies have shown a reciprocal influence of different tree species or plant communities on the soil ecosystem in different ecological zones (Oyeniyi and Aweto, 1986; Adejuwon and Ekanade, 1988; Awotoye et al., 2009). The accumulation of organic matter in soil can greatly increase the cation exchange capacity and have positive impacts on the nutrient holding capacity of that soil (Berg and McClaugherty, 2008). The study of Michel et al., (2010), reported significant reduction in soil organic carbon content and $\mathrm{pH}$ in multispecies tree plantation, cocoa plantation and mixed-crop fields compare to natural forest. According to Parrotta (1999), mixed plantation has the tendency to modify degraded soil and enhanced nutrient recycling regardless of the tree species origin.

In order to avoid the consequence of bad silviculture management; there has been an increased interest among foresters on the value of a proper mixture as a factor in the successful establishment and management of plantations (Ojo, 2005). Mixed forest types are currently recommended by foresters in order to improve the stability and biodiversity value of forest ecosystems (Hooper et al., 2005). Therefore, this study was set out to assess the litter decomposition rate and determine the nutrient levels of soils under different tree species combinations.

\section{Materials and Methods}

The study was carried out in Ogbese Forest Reserve, Ekiti State of South-Western Nigeria. The reserve covers an area of $72.52 \mathrm{~km}^{2}$ and lies approximately between Lat. $7^{0} 31^{1}$ and $7^{0}$ $49^{1} \mathrm{~N}$ and Long. $5^{0} 7^{1}$ and $5^{0} 27^{1} \mathrm{E}$. The forest reserve composed of plantation of various mixtures of tree species such as (Terminalia sp and Tectona grandis; Gmelina arborea and Tectona grandis; Khaya sp and Tectona grandis; Theobroma cacao and Cola sp.) established in 1998 by manual clearing of the former vegetation. The existing vegetation of the undisturbed natural forest is characterized with abundant forest trees species of different families and general. The vegetation is dominated by mature tree species with moderate numbers of climbers, shrubs and herbs.

\subsection{Soil Nutrient Measurements}

A total of 90 soil samples were collected from all the five tree species combinations using a stainless steel auger. In each of the site, the three plots $(25 \mathrm{~m} \mathrm{x} 25 \mathrm{~m})$ were randomly mapped out from which two composite soil samples to the depths of $0-15 \mathrm{~cm}$ and $15-30 \mathrm{~cm}$ were collected by simple random technique method. The composite samples were dried and sieved using $2 \mathrm{~mm}$ sieve for laboratory analysis.

The soil bulk density was determined by core method and particle size was determined by hydrometer method. The organic carbon was determined by Walkley-Black wet oxidation method (Nelson and Sommers, 1982), while the total nitrogen was determined by the micro-Kjeldal digestion method (Bremner and Mulvaney, 1982). Also, the soil pH was measured electrometrically in water at 1:2 soil /water ratio using $\mathrm{pH}$ meter, available phosphorus was determined by Bray P1 method while exchangeable cations $\left(\mathrm{K}^{+}, \mathrm{Na}^{+}\right.$, $\mathrm{Ca}^{2+}$, and $\mathrm{Mg}^{2+}$ ) were determined using $1 \mathrm{M} \mathrm{NH} \mathrm{NH}_{4} \mathrm{OAc}$ buffered at $\mathrm{pH} 7.0$ as extractant (Thomas, 1982). The $\mathrm{K}^{+}$and $\mathrm{Na}^{+}$concentrations were read by flame photometry while $\mathrm{Ca}^{2+}$ and $\mathrm{Mg}^{2+}$ concentrations were read using atomic absorption spectrophotometer. The exchangeable acidity $\left(\mathrm{Al}^{3+}\right.$ and $\left.\mathrm{H}^{+}\right)$was determined by standard $\mathrm{NaOH}$ titration method.

\subsection{Litter Collection and Decomposition Rate Determination}

Freshly senesced leaf material was collected with twelve 5 $\mathrm{m} \times 5 \mathrm{~m}$ litter trap mounted in each of the five sampling sites. The litters were weighed and dried $\left(70{ }^{\circ} \mathrm{C}\right.$ for 48 hours $) .10 \mathrm{~g}$ of the oven dried leaf material per site were placed in litter bag. Litter decomposition was determined by litter bag technique. We used a total of 45 nylon litter bags, three replicate litter bags $(20 \mathrm{~cm} \times 20 \mathrm{~cm}, 1 \mathrm{~mm}$ nylon mesh) for each of the three plot ( $25 \mathrm{~m} \times 25 \mathrm{~m})$ in each sites. These were randomly placed in the corresponding tree species combination plots and their rate of decomposition were monitored at 2, 4, 6 and 8 weeks and the kinetic of litter decay were monitored by determining weight loss during decomposition. Litter decomposition rate was determined with the formula

$$
\mathrm{Mt}=\mathrm{Mo} \exp (-\mathrm{kt})
$$

expressed as

$$
\operatorname{In}(\mathrm{Mo} / \mathrm{Mt})=\mathrm{kt}
$$

Where

Mo $=$ Mass of litter at time o,

$\mathrm{Mt}=$ Mass of litter at time $\mathrm{t}$,

$\mathrm{t}=$ time of incubation in weeks, and 
$\mathrm{k}=$ decomposition rate constants (Wood, 1974).

The results of the soil tests carried out were subjected to inferential statistics using one way ANOVA and Duncan multiple range test were used to find the differences in the mean scores. An index of deterioration was determined for the vegetation and soil variables according to the procedure outlined by (Ekanade et al., 1991).

\section{Results}

The litter accumulation in the forest plantation was in the magnitude of Gmelina arborea and Tectona grandis $\left(1249.20 \mathrm{~kg} \mathrm{ha}^{-1}\right)>$ Khaya $\mathrm{sp}$ and Tectona grandis $(899.42$ $\left.\mathrm{kg} \mathrm{ha}^{-1}\right)>$ Terminalia sp and Tectona grandis $(867.58 \mathrm{~kg} \mathrm{ha}$ $\left.{ }^{1}\right)>$ natural forest $\left(489.96 \mathrm{~kg} \mathrm{ha}^{-1}\right)>$ Theobroma cacao and Cola $\mathrm{sp}\left(199.87 \mathrm{~kg} \mathrm{ha}^{-1}\right)$. In the natural forest the litter accumulation was reduced by $77.00 \%$ compared with agroforestry plantation.

The rate of litter decomposition at two weeks varied among the different species combinations (Figure 1). However, rates of decomposition were similar at four and six weeks under Tectona grandis and Gmelina, Theobroma cacao and Cola combinations and natural forest. The Tectona grandis and Khaya, Teak and Gmelina

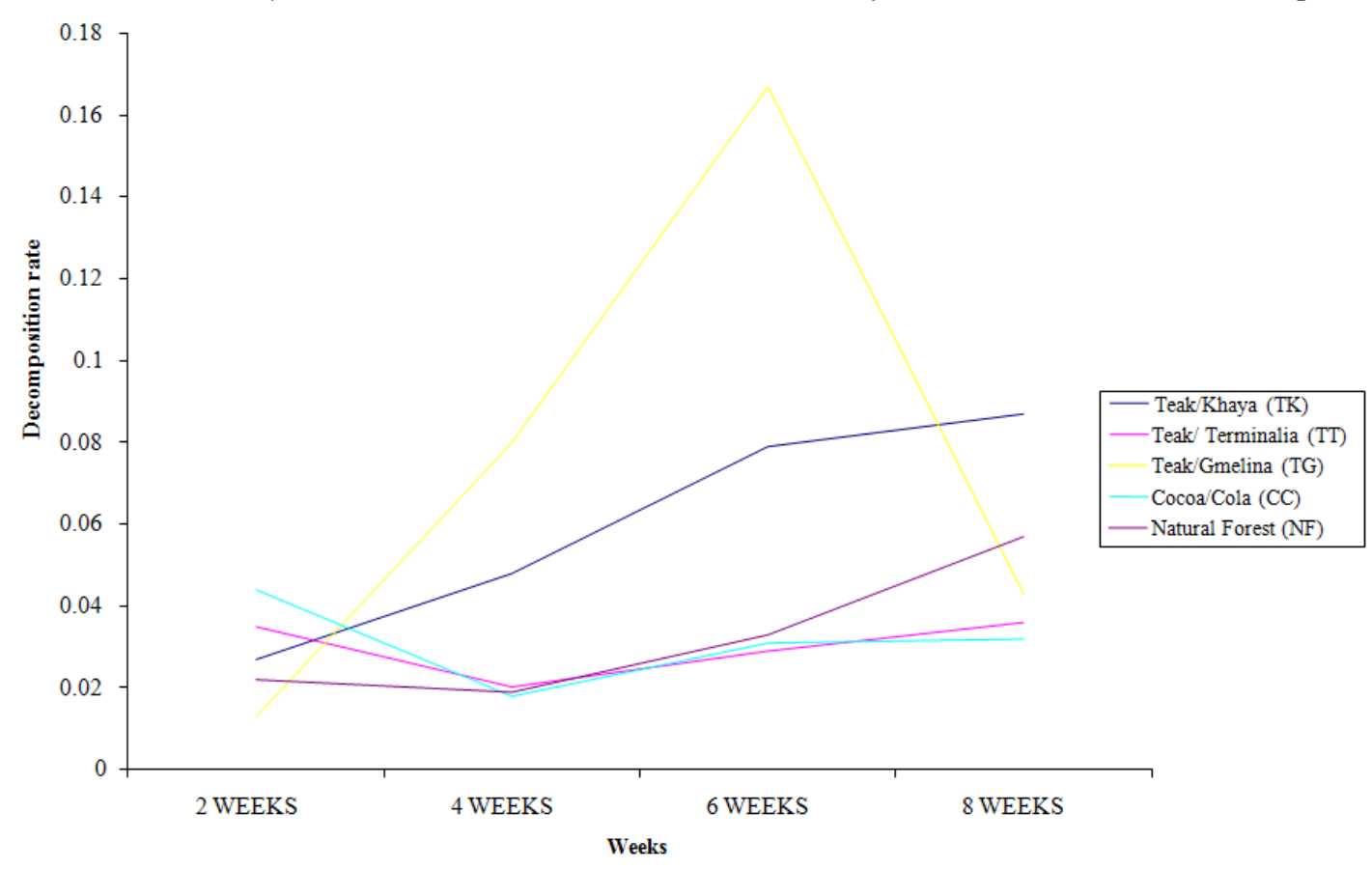

Figure 1. Litter decomposition rate under different species combinations at 2, 4, 6 and 8 weeks

The sand content in Tectona grandis and Khaya sp plot at 15-30 cm depth showed a similar relationship with that of the top soil, while Theobroma cacao and cola had lowest sand content. The sand content at $15-30 \mathrm{~cm}$ soil depth in the tree crop plantation was low compared to the top soil. The pattern of significant differences due to different tree species combination as observed at $0-15 \mathrm{~cm}$ depth was repeated at $15-30 \mathrm{~cm}$. Generally, the sand content in the various plots decrease with increase in depth, but for textural classes Tectona grandis and Khaya sp plot was combinations had higher rate of decomposition than other tree species combinations. The decomposition rate of Tectona grandis and Gmelina arborea was 5.3 times higher than that of Tectona grandis and Terminalia sp, Theobroma cacao and cola combinations and natural forest at 6 weeks. However, decomposition rate of Tectona grandis and Gmelina arborea decline suddenly at 8 weeks by $74.25 \%$.

Table 1 shows the influence of the different tree species combinations on the soil physical properties at $0-15 \mathrm{~cm}$ and 15-30 cm depths. Tectona grandis and Khaya sp plot had the highest sand content at $0-15 \mathrm{~cm}$ depth while Tectona grandis and Terminalia sp plot had the least value. There were significant differences in the sand contents between the plots, even though the tree combinations were both fast growing exotic and indigenous species. The clay content in Tectona grandis and Khaya, Tectona grandis and Gmelina combinations and natural forest did not show any significant difference. However, high clay content were observed in both Tectona grandis mixed with Terminalia sp; and Theobroma cacao mixed with cola plots. The silt content under Tectona grandis mixed with Gmelina arborea plot was significantly higher than the other tree species combinations. There was no significant difference in the bulk density of the soil across the various plots. observed to be sandy soil. The textural class changed from loamy sand to sandy loam under Tectona grandis and Terminalia $s p$ mixture and Theobroma cacao and cola mixture with increase in soil depth. Similar change was observed under natural forest except that the sandy soil at 0 $15 \mathrm{~cm}$ was modified to sandy loam at $15-30 \mathrm{~cm}$. The soil bulk densities under Tectona grandis and Khaya $s p$ and natural forest were significantly lower than other tree species combinations. 
Table 1. Particle size analysis and bulk density of soil at 0-15 cm and 15-30 cm under different tree species combinations

\begin{tabular}{|c|c|c|c|c|c|c|}
\hline Soil Depth & Tree species combinations & $\%$ Sand & $\%$ Clay & $\%$ Silt & Textural Class & Bulk Density \\
\hline \multirow[t]{5}{*}{$0-15 \mathrm{~cm}$} & Teak/Khaya (TK) & $89.65^{\mathrm{a}}$ & $4.37^{\mathrm{b}}$ & $5.96^{\mathrm{d}}$ & Sandy & $1.20^{\mathrm{a}}$ \\
\hline & Teak/ Terminalia (TT) & $76.73^{\mathrm{c}}$ & $7.87^{\mathrm{a}}$ & $15.40^{\mathrm{b}}$ & Loamy sand & $1.21^{\mathrm{a}}$ \\
\hline & Teak/Gmelina (TG) & $78.23^{\mathrm{c}}$ & $4.54^{\mathrm{b}}$ & $17.23^{\mathrm{a}}$ & Loamy sand & $1.25^{\mathrm{a}}$ \\
\hline & Cocoa/Cola (CC) & $77.07^{\mathrm{c}}$ & $7.48^{\mathrm{a}}$ & $15.68^{\mathrm{b}}$ & Loamy sand & $1.13^{\mathrm{a}}$ \\
\hline & Natural Forest (NF) & $86.23^{\mathrm{b}}$ & $4.64^{\mathrm{b}}$ & $9.12^{\mathrm{c}}$ & Sandy & $1.10^{\mathrm{a}}$ \\
\hline \multirow[t]{5}{*}{$15-30 \mathrm{~cm}$} & Teak/Khaya (TK) & $87.50^{\mathrm{a}}$ & $4.90^{\mathrm{b}}$ & $7.60^{\mathrm{e}}$ & Sandy & $1.20^{\mathrm{c}}$ \\
\hline & Teak/ Terminalia (TT) & $73.80^{\mathrm{c}}$ & $10.00^{\mathrm{a}}$ & $16.20^{\mathrm{c}}$ & Sandyloam & $1.45^{\mathrm{a}}$ \\
\hline & Teak/Gmelina (TG) & $77.40^{\mathrm{b}}$ & $4.52^{\mathrm{b}}$ & $18.10^{\mathrm{b}}$ & Loamysand & $1.40^{\mathrm{a}}$ \\
\hline & Cocoa/Cola $(\mathrm{CC})$ & $70.00^{\mathrm{d}}$ & $9.60^{\mathrm{a}}$ & $20.40^{\mathrm{a}}$ & Sandyloam & $1.45^{\mathrm{a}}$ \\
\hline & Natural Forest (NF) & $85.30^{\mathrm{a}}$ & $4.80^{\mathrm{b}}$ & $9.90^{\mathrm{d}}$ & Loamysand & $1.19^{\mathrm{b}}$ \\
\hline
\end{tabular}

Means with the same letter(s) are not significantly different by Duncan's Multiple Range Test at $\mathrm{P}<0.05$

Table 2 shows the soil chemical characteristics at $0-15$ and $15-30 \mathrm{~cm}$ respectively under different tree species combinations. Soil pH ranged between 6.76 in Teak and Gmelina, cocoa and cola, and 6.90 in Teak and Khaya. The soil $\mathrm{pH}$ within the different plots was significantly different at $(\mathrm{P}<0.05)$ although they were all near neutral $\mathrm{pH}$. The organic carbon and available Nitrogen at $0-15 \mathrm{~cm}$ soil depth under Teak and Khaya combinations were significantly lower compared with other trees species combinations. The $\mathrm{C} / \mathrm{N}$ ratio showed no significant difference between the plots at 0 $15 \mathrm{~cm}$.

Table 2. Chemical characteristics at 0-15 cm and 15-30 cm soil depths under different tree species combinations

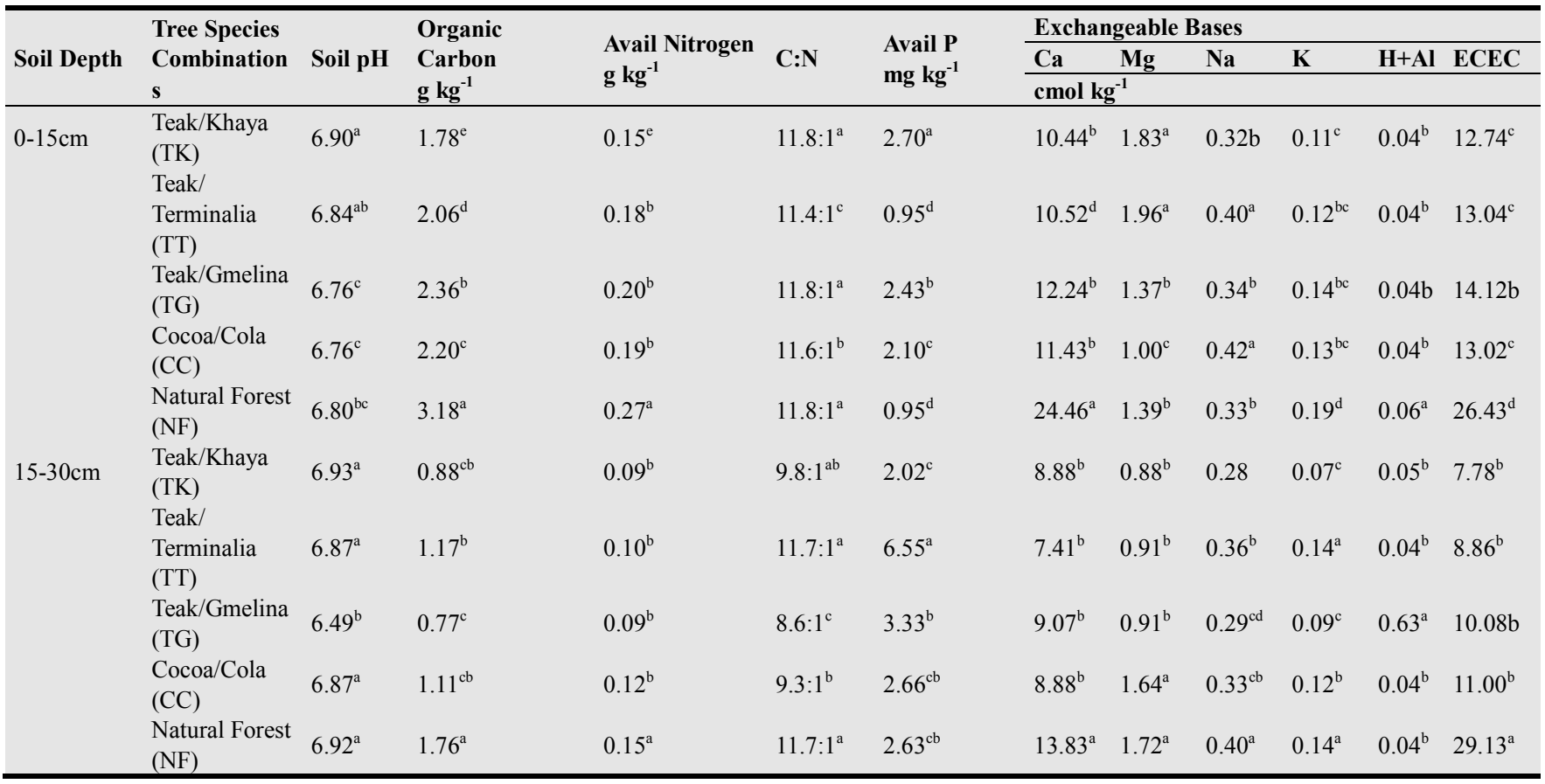

Table 2. Continued

\begin{tabular}{|c|c|c|c|c|c|c|}
\hline \multirow{2}{*}{ Soil Depth } & \multirow{2}{*}{ Tree Species Combinations } & \multirow{2}{*}{ Base Salt \% } & $\mathrm{Cu}$ & Zn & $\mathbf{F e}$ & Mn \\
\hline & & & \multicolumn{4}{|l|}{$\mathrm{mg} \mathrm{kg}^{-1}$} \\
\hline \multirow[t]{5}{*}{$0-15 \mathrm{~cm}$} & Teak/Khaya (TK) & $99.67^{b}$ & $0.63^{\mathrm{c}}$ & $8.22 \mathrm{c}$ & $2.58^{\mathrm{b}}$ & $57.65 \mathrm{a}$ \\
\hline & Teak/ Terminalia (TT) & $99.67^{b}$ & $2.03^{\mathrm{a}}$ & $9.07^{\mathrm{b}}$ & $1.89 \mathrm{c}$ & $45.75 b$ \\
\hline & Teak/Gmelina (TG) & $99.71^{\mathrm{ab}}$ & $0.70^{\mathrm{c}}$ & $3.99^{\mathrm{c}}$ & $0.66^{\mathrm{c}}$ & $27.59^{d}$ \\
\hline & Cocoa/Cola (CC) & $99.72^{\mathrm{ab}}$ & $1.29^{\mathrm{b}}$ & $734^{\mathrm{d}}$ & $1.45 \mathrm{~d}$ & $39.22^{\mathrm{c}}$ \\
\hline & Natural Forest (NF) & $99.78^{\mathrm{d}}$ & $0.75^{\mathrm{d}}$ & $12.05^{\mathrm{a}}$ & $3.55^{\mathrm{a}}$ & $13.93^{\mathrm{c}}$ \\
\hline \multirow[t]{5}{*}{$15-30 \mathrm{~cm}$} & Teak/Khaya (TK) & $99.41^{\mathrm{b}}$ & $0.40^{\mathrm{bc}}$ & $8.73^{\mathrm{b}}$ & $2.81^{\mathrm{a}}$ & $56.93^{\mathrm{a}}$ \\
\hline & Teak/ Terminalia (TT) & $99.57^{\mathrm{a}}$ & $0.78^{\mathrm{a}}$ & $6.70^{\mathrm{c}}$ & $1.56^{\mathrm{b}}$ & $57.63^{\mathrm{a}}$ \\
\hline & Teak/Gmelina (TG) & $99.35^{\mathrm{b}}$ & $0.31^{\mathrm{c}}$ & $7.26^{\mathrm{c}}$ & $0.67^{\mathrm{c}}$ & $35.96^{\mathrm{b}}$ \\
\hline & Cocoa/Cola (CC) & $99.67^{\mathrm{a}}$ & $0.69^{\text {ba }}$ & $2.27^{\mathrm{d}}$ & $1.94^{\mathrm{b}}$ & $60.15^{\mathrm{a}}$ \\
\hline & Natural Forest (NF) & $99.71^{\mathrm{a}}$ & $0.25^{\mathrm{c}}$ & $17.29^{\mathrm{a}}$ & $2.91^{\mathrm{a}}$ & $37.77^{\mathrm{b}}$ \\
\hline
\end{tabular}


Available phosphorus was significantly higher under Teak and Khaya compared with other tree species combinations. The $\mathrm{Ca}^{2+}$ and $\mathrm{K}^{+}$contents under the different tree combinations were significantly lower than the natural forest; however, the other exchangeable bases such as $\mathrm{Mg}^{2+}$ and $\mathrm{Na}^{+}$ did not follow a definite pattern. The ECEC under natural forest was between 80-110\% higher than the other different tree species mixtures. Similarly, $\mathrm{Zn}^{2+}$ and $\mathrm{Fe}^{2+}$ content under the natural forest were significantly higher than other tree species combinations. In contrast, $\mathrm{Cu}^{2+}$ and $\mathrm{Mn}$ were significantly lower in natural forest than in other tree species combinations.

At 15-30 cm soil depth the mixture of Teak and Gmelina showed the least values of soil $\mathrm{pH}$, organic carbon and available Nitrogen. The $\mathrm{C} / \mathrm{N}$ ratio was in the magnitude of Teak and Gmelina $(8.6: 1)<$ cocoa and cola $(9.3: 1)<$ Teak and Khaya (9.8:1) < Teak and Terminalia (11.7:1) Natural forest. The subsoil level under Teak and Terminalia was significantly rich in available $\mathrm{P}\left(6.55 \mathrm{mg} \mathrm{kg}^{-1}\right)$. However, the exchangeable bases did not follow this pattern. The natural forest had significantly high value in respect of $\mathrm{Ca}^{2+}$, while cocoa and cola plantation with natural forest were higher in $\mathrm{Mg}$ than other tree species plantations. The ECEC under natural forest was also significantly $\left(29.13 \mathrm{mg} \mathrm{kg}^{-1}\right)$ higher than other plantations. Other elements such as $\mathrm{Cu}, \mathrm{Zn}$ and $\mathrm{Fe}$ did not follow a definite pattern with different species combinations.

Table 3. Deterioration index of soil chemical properties at 0-15 cm and 15-30 cm soil depths under different tree species combinations

\begin{tabular}{|c|c|c|c|c|c|c|c|c|c|c|c|}
\hline \multirow{3}{*}{ Soil Depth } & \multirow{3}{*}{$\begin{array}{l}\text { Tree Species } \\
\text { Combinations }\end{array}$} & \multirow{3}{*}{ Soil pH } & \multirow{3}{*}{$\begin{array}{l}\text { Carbon } \\
\mathrm{g} \mathrm{kg}^{-1}\end{array}$} & \multirow{3}{*}{$\begin{array}{l}\text { Nitrogen } \\
\mathrm{g} \mathrm{kg}^{-1}\end{array}$} & \multirow{3}{*}{$\begin{array}{l}\text { Avail P } \\
\mathrm{mg} \mathrm{kg}^{-1}\end{array}$} & \multicolumn{6}{|c|}{ Exchangeable Bases } \\
\hline & & & & & & $\mathbf{C a}$ & Mg & $\mathrm{Na}$ & $\mathbf{K}$ & $\mathbf{H}+\mathbf{A l}$ & ECEC \\
\hline & & & & & & \multicolumn{6}{|c|}{$\mathrm{cmol} \mathrm{kg}^{-1}$} \\
\hline \multirow[t]{4}{*}{$0-15 \mathrm{~cm}$} & Teak/Khaya (TK) & -0.01 & 0.44 & 0.45 & -1.84 & 0.57 & -0.32 & 0.03 & 0.42 & 0.33 & 0.52 \\
\hline & Teak/ Terminalia (TT) & -0.01 & 0.35 & 0.33 & 0 & 0.57 & -0.41 & -0.21 & 0.37 & 0.33 & 0.51 \\
\hline & Teak/Gmelina (TG) & 0.01 & 0.26 & 0.26 & -1.56 & 0.5 & 0.01 & -0.03 & 0.26 & 0.33 & 0.47 \\
\hline & Cocoa/Cola (cc) & 0.01 & 0.31 & 0.3 & -1.21 & 0.53 & 0.28 & -0.27 & 0.32 & 0.33 & 0.51 \\
\hline \multirow[t]{4}{*}{$15-30 \mathrm{~cm}$} & Teak/Khaya (TK) & -0.01 & 0.5 & 0.4 & 0.23 & 0.36 & 0.49 & 0.3 & 0.5 & -0.25 & 0.73 \\
\hline & Teak/ Terminalia (TT) & 0.01 & 0.34 & 0.33 & -1.49 & 0.46 & 0.47 & 0.1 & 0 & 0 & 0.7 \\
\hline & Teak/Gmelina (TG) & 0.06 & 0.56 & 0.4 & -0.27 & 0.34 & 0.47 & 0.28 & 0.36 & -14.75 & 0.65 \\
\hline & Cocoa/Cola (cc) & 0.01 & 0.37 & 0.2 & -0.01 & 0.36 & 0.05 & 0.18 & 0.14 & 0 & 0.62 \\
\hline
\end{tabular}

Table 3. Continued

\begin{tabular}{|c|c|c|c|c|c|c|}
\hline \multirow{2}{*}{ Soil Depth } & \multirow{2}{*}{ Tree Species Combinations } & \multirow{2}{*}{ Base Salt \% } & $\mathrm{Cu}$ & Zn & $\mathbf{F e}$ & Mn \\
\hline & & & \multicolumn{4}{|c|}{$\mathrm{mg} \mathrm{kg}^{-1}$} \\
\hline \multirow[t]{4}{*}{$0-15 \mathrm{~cm}$} & Teak/Khaya (TK) & 0.001 & -1.52 & 0.32 & 0.27 & -3.14 \\
\hline & Teak/ Terminalia (TT) & 0.001 & -7.12 & 0.25 & 0.47 & -2.28 \\
\hline & Teak/Gmelina (TG) & 0.001 & -1.8 & 0.67 & 0.81 & -0.98 \\
\hline & Cocoa/Cola (cc) & 0.001 & -4.16 & 0.39 & 0.59 & -1.82 \\
\hline \multirow[t]{4}{*}{$15-30 \mathrm{~cm}$} & Teak/Khaya (TK) & 0.003 & -0.6 & 0.5 & 0.03 & \\
\hline & Teak/ Terminalia (TT) & 0.001 & -2.12 & 0.61 & 0.46 & \\
\hline & Teak/Gmelina (TG) & 0.003 & -0.24 & 0.58 & 0.77 & \\
\hline & Cocoa/Cola (cc) & 0.001 & -1.76 & 0.87 & 0.33 & \\
\hline
\end{tabular}

Table 4. Correlation coefficient of soil chemical properties with rate of decomposition at 4,6 and 8 weeks.

\begin{tabular}{llll}
\hline Elements & Rate of Decomp. at 4 weeks & Rate of Decomp. at 6 weeks & Rate of Decomp. at 8 weeks \\
\hline $\mathrm{pH}$ & -0.23 & $-0.57^{* *}$ & $-0.48^{* *}$ \\
$\mathrm{Ca}$ & -0.13 & 0.22 & -0.14 \\
$\mathrm{Mg}$ & -0.15 & $-0.33^{*}$ & $-0.35^{*}$ \\
$\mathrm{Na}$ & 0.21 & $0.37^{*}$ & $0.58^{* *}$ \\
$\mathrm{~K}$ & -0.15 & 0.27 & 0.03 \\
$\mathrm{Pc}$ & 0.02 & -0.09 & 0.09 \\
Avail P & $-0.40^{* *}$ & -0.99 & $0.04 * *$ \\
\hline
\end{tabular}

* Significant at $\mathrm{p}<0.05$

** Significant at $\mathrm{p}<0.01$ 
Table 3 shows deterioration indices of some soil chemical properties at $0-15 \mathrm{~cm}$ and $15-30 \mathrm{~cm}$ soil depths respectively. At $0-15 \mathrm{~cm}$ soil depth, the mixture of the tree species of Teak with Khaya plot and Teak with Terminalia plot did not deteriorate in terms of soil $\mathrm{pH}$. Similarly, the mixture of Teak with Gmelina, and cocoa with cola did not have pronounced negative effect on the soil $\mathrm{pH}$ at $0-15 \mathrm{~cm}$ depth. The deterioration index of organic carbon and available nitrogen were lower under Teak mixture $(0.026,0.26)$ compared with other tree species combinations. There was no negative effect of different mixture of tree species on the available soil phosphorus. In contrast, the exchangeable bases $\left(\mathrm{Ca}^{2+}, \mathrm{Mg}^{2+}\right.$, $\mathrm{Na}^{+}$and $\mathrm{K}^{+}$), the exchangeable acidity $\left(\mathrm{Al}^{3+}\right.$ and $\left.\mathrm{H}^{+}\right)$and ECEC showed different levels of deterioration under different tree species mixtures. Similarly, deterioration indices of $\mathrm{Zn}$ and $\mathrm{Fe}$ varied among the tree species mixtures. However, the different mixtures of tree species had no deterioration effect on the soil $\mathrm{Cu}$ and $\mathrm{Mn}$ at $0-15 \mathrm{~cm}$ depth. At $15-30 \mathrm{~cm}$ depth, the trend in the deterioration indices were similar to that of the top soil except for available $\mathrm{P}$ under Teak and Khaya mixture where pronounced effect of the mixture was observed on the soil P.

The result of the dendograme (Figure 2) showed that the soil characteristics in the various tree species combination plot were similar up to $50 \%$ when clustered into four groups as: (1) Sand, ECEC, $\mathrm{Zn}$ and $\mathrm{Fe},(2) \mathrm{pH}, \mathrm{Mg}, \mathrm{Na}$ and $\mathrm{Cu}$ (3) $\mathrm{Ca}, \mathrm{K}, \mathrm{BS}, \mathrm{PC}$ and PN and (4) Clay, Silt, H-Al, Available P and $\mathrm{Mn}$. Furthermore, the first two groups were related up to $40 \%$ in their soil characteristics while the first three groups showed low relationship up to $30 \%$. However, the whole variables were related only up to $10 \%$. Table 5 gave positive relationship between the soil chemical properties and rate of decomposition of litter falls of the species combinations.

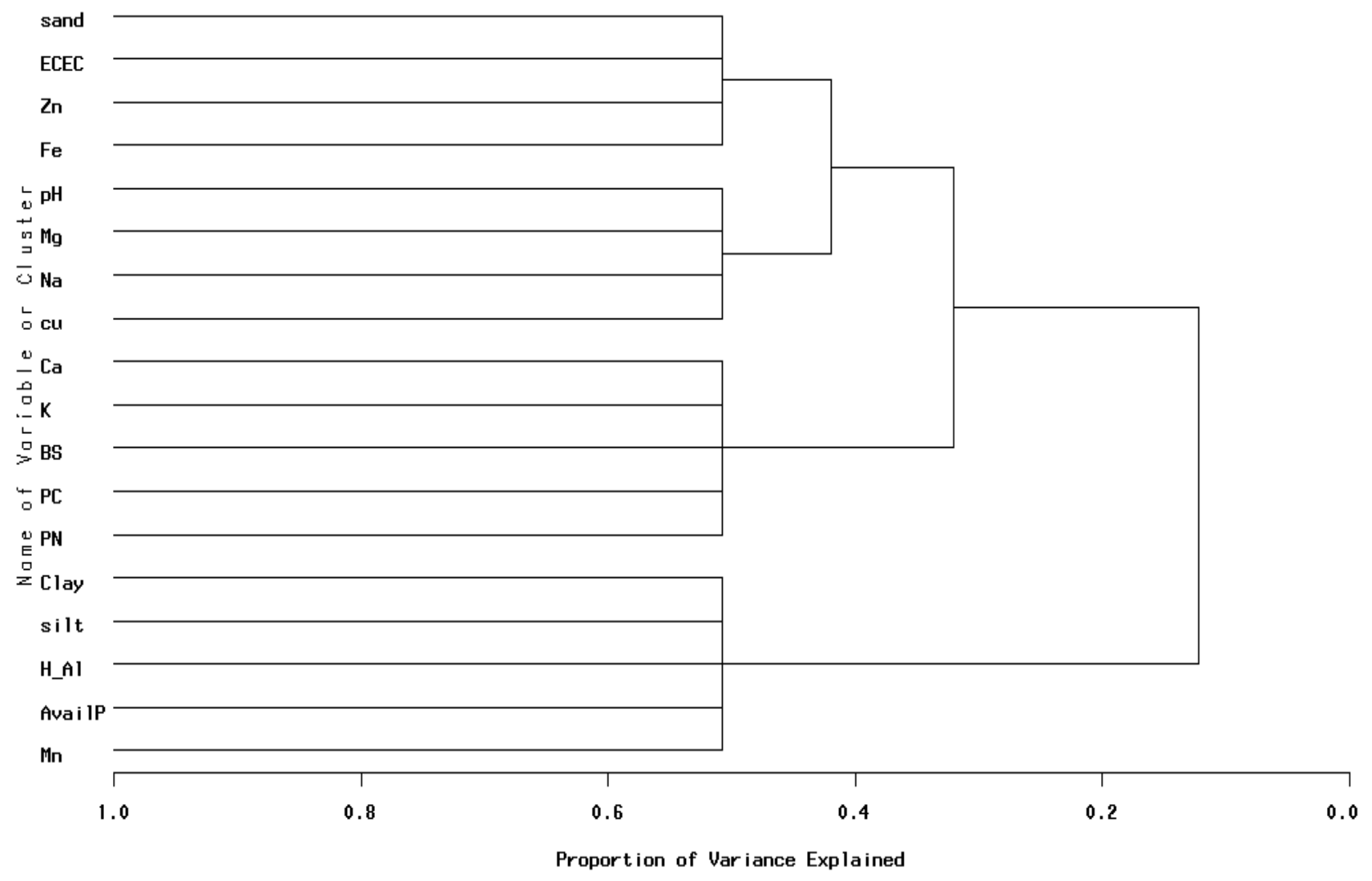

Figure 2. Inter-Relationship between the Soil Properties under the Various Species Combination

\section{Discussion}

The litter accumulation pattern observed in this study showed that Teak in combination with other tree species had higher litter accumulation. This agrees with Ojo (2005) who observed a massive litter accumulation in Teak plantation in Akure forest reserve. However, variation in litter accumulation among plantations could be attributed to some factors such as the number of trees in the ecosystem, type of species and size. Weaner et al., (1987) observed that trees of greater timber size tend to have more litters.
Litters act as input-output system of nutrients and their decomposition is the primary mechanism by which organic matter and nutrients are returned to the soil for reabsorption by the growing plants. The fast rate of decomposition observed in the litters of tree species at the early stage decomposition in this study is in line with the decomposition characteristics of tropical tree species which had been reported by many workers (Kumar and Deepu, 1992 and Awotoye et al., 2009). The contributing factors had been attributed to favourable moisture and temperature regimes (Sreekala et al., 2001). However, the pronounced variation in 
the pattern of decomposition rate observed in the plantations as expressed in Teak and Khaya sp, Teak and Gmelina arborea compared to Teak and Terminalia sp, cocoa and cola mixtures may not be unconnected with different foliar chemical compositions of different tree species within the plantations. Decomposition of organic material is affected by its biochemical properties (Parrotta, 1999). Some species have been reported to have lignin content which can render some of the cellulose and the other constituents inaccessible to the microflora.

Soil physical and chemical properties have been proposed by some workers as indicators for assessing the effect of land use management (Janzen et al., 1992; Bremer et al., 1994; Alvarez and Alvarez, 2000). Top soil morphological characteristics between the various tree species combination plots showed no significant difference in bulk density. This could be explained by the low activities such as hunting, fuel wood gathering, and picking of snail within the forest plantations. In contrast to natural forest, most artificial forest plantations in the tropics are free from human and animal interferences because of reduced undergrowth. Trampling of pasture by cattle has been shown to increase bulk density of active pasture over that of undisturbed forest. The low sand content at $15-30 \mathrm{~cm}$ soil depth in different tree species combination plots as against the top soil conformed to the findings of Onyekwelu et al., (2006) at Oluwa and Omo forest reserves. They reported a decrease in sand content in Gmelina arborea plantation sites as the soil depth increases and, an increase in the clay and silt contents as you go down the soil profile.

The soil chemical characteristics under the various species combinations showed significant differences in properties. Significant difference in $\mathrm{pH}$ may be due to leaching of base elements. Onyekwelu et al., (2006) observed that nutrients are swiftly leached by heavy precipitation in the tropical rainforest. The organic matter and available nitrogen contents under various tree species combination was significantly lower to that of natural forest, this may be due to lack of understorey vegetation that often associate with teak plantation even in a mixture with other species. Juo and Manu (1996) found that growing vegetation tended to decrease soil $\mathrm{pH}$, with low nutrient stocks. This often exposes the soil to soil erosion.

Tree plantations are often used in forest rehabilitation and restoration to foster regenerating tree species, protect soil and increase the concentration of soil nutrients such as N, P, K, $\mathrm{Ca}$ and $\mathrm{Mg}$ (Parrotta, 1992 and Leopold et al, 2001). The result of this study has revealed that planting Tectona grandis in combination with other tree species especially indigenous fast growing species has potentials for maintaining soil nutrient level. The $\mathrm{C} / \mathrm{N}$ ratio of the soil under different tree species combination did not show any significant difference to that of natural forest. This implies that a mixed plantation could naturally sustain its nutrient level under efficient silvicultural practice. In a study of 5 year old pure and mixed species plantations, Montagnini (2000) observed that mixed plantations will take longer time to diminish soil nutrients.
Also, Parrotta (1999) found that soil $\mathrm{K}, \mathrm{Mg}, \mathrm{Na}$, and $\mathrm{Fe}$ concentrations were greater in mixed plantations than each species in plantation separately.

The low $\mathrm{Ca}$ and $\mathrm{K}$ contents under the different tree combinations as against that of natural forest contradict the findings of (Nwoboshi, 1970). Nwoboshi (1970) reported high $\mathrm{Ca}$ concentration in soil especially at peak leaf fall. Similarly, Singh et al., (1985) reported high concentration of exchangeable $\mathrm{Ca}, \mathrm{Mg}$ and $\mathrm{K}$ under teak plantation. This variation may likely due to the mixture of teak with other tree species. Tucker and Murphy, 1997 and Hartey, 2002 were of the opinion that mixed species plantations could further accelerate the restoration process of degraded soil. However, the ability of tree species combination to improve the nutrient status of the soil would depend on a good and an appropriate choice of tree species combinations. When indigenous species with lesser growing characteristics is mixed with fast growing exotic species in a plantation, this may mitigate the demand of soil nutrient by fast growing species. Narong et al., (2007) opined that teak should be mixed with other tree species during the commencement of plantation establishment.

\section{Conclusion}

The differences in the litter accumulation and rate of decomposition in the tree mixture induced significant soil nutritional differences among the combinations. Teak and Gmelina arborea had the highest quantity of litter and faster rate of decomposition, which is an index to high nutrient release to the soil under this combination. The observed relative nutrient availability within the structurally different forested ecosystem in the study area might not be unconnected to the litter mixtures emerging from different tree combinations.

\section{Acknowledgments}

The authors are grateful to the Management of the Ekiti State Ministry Environment, Department of Forestry for allowing us to conduct the research in their forest reserve.

\section{References}

[1] Adejuwon, J.O. and Ekanade, O. (1988). Soil Changes Consequent upon the Replacement of Tropical Rainforest by Plantations of Gmelina arborea, Tectona grandis and Terminalia superba. Journal of World Forest Resources Management 3: 47-59.

[2] Alvarez, R. and Alvarez, C. R. (2000). Soil organic matter pools and their association with carbon mineralization kinetics. Journal of America society Soil Science 64(1): 184-189.

[3] Awotoye, O. O., Ekanade O. and Airouhudion O. (2009). Degradation of the physicochemical properties resulting from continuous logging of Gmelina arborea and Tectona grandis plantations. African Journal of Agricultural Research. 4(11): 1317-1324. 
[4] Baldock J.A., Masiello C.A., Gelinas Y., Hedges J.I.,(2004). Cycling and composition of organic matter in terrestrial and marine ecosystems, Marine Chemistry 92 (2004) 39- 64

[5] Berg, B., and McClaugherty, C. (2008). Plant Litter; Decomposition, Humus Formation, Carbon Sequestration second edition, Springer-Verlag Berlin Heidelberg1-340. Ebook available on www.springer.com

[6] Binkley, D., and Resh, S. C., (1999). Rapid changes in soils following eucalyptus afforestation in Hawaii. Journal of America Soil Science Society 63:222-225.

[7] Bremner, J. M. and Mulvaney C. S. (1982). Nitrogen- Total. In: Methods of soil analysis. Page, A. L. et al. (eds). Methods of Soil Analysis. Part 2. Agron. Monogr. 9. Second Edition. pp 595-624. ASA and SSSA. Madison, Wisconsin, U.S.A.

[8] Brockerhoff, E. G., Ecroyd, C. E. and Langer, E. R., (2001). Biodiversity in New Zealand plantation forests: policy trends, incentives, and the state of our knowledge. New Zealand Journal of Forestry 46: 31-37.

[9] Ekanade, O.; Adesina, F.A. and Egbe, N.E. (1991). Sustaining Tree Crop Production under Intensive Land Use: An Investigation into Soil Quality Differentiation under Varying Cropping Patterns in Western Nigeria. Journal of Environmental Management. 32: 105-113.

[10] Forrester, D.I.; Bauhus, J. and Khanna, P.K. (2004). Growth Dynamics in a Mixed Species Plantation of Eucalyptus globules and Accacia mearnsii. Forest, Ecology and Management. 193: 81-95.

[11] Hartley, M.J. (2002). Rationale and Methods for Conserving Biodiversity in Plantation Forests. Forest, Ecology and Management. 155: 81-95.

[12] Hertel, D., Harteveid, M. A. and Leuschner, C. (2009). Conversion of a Tropical Forest into Agroforest Alters the Fine root-related Carbon Flux to Soil. Soil Biology and Biochemistry. 41: 481-490

[13] Hooper, D.U., Chapin, F.S., Ewel, J.J., Hector, A., Inchausti, P., Lavorel, S. et al. (2005). Effects of biodiversity on ecosystem functioning: a consensus of current knowledge. Ecol. Monogr., $75,3-35$.

[14] Janzen, H. H., Campbell, C. A., Brant, S. A., Lanfond, G. P. and Townley, S. (1992). Light-fraction organic matter in soils from long-trm crop rotations. Journal of Soil Biology and Biochemistry. 8: 200-213.

[15] Juo, A. S. R. and Manu, A. (1996). Nutrient effect on modification of shifting cultivation in West Africa. Journal of Agriculture, Ecosystem and Environment. 58: 49-60.

[16] Kumar, and Deepu, J.K. (1992). Litter Production and Decomposition Dynamics in Moist, Deciduous Forests of the Western Ghats in Peninsular India. Forest, Ecology and Management. 50:181-201.

[17] Leopold, C.; Andrus, R.; Firkeldey, A. and Knowles, D. (2001). Attempting Restoration of Wet Tropical Forests in Costa Rica. Forest, Ecology and Management 142: 243-249.

[18] Michel, K. Y., Pascal, K. T. A., Souleymane, K., Jerome, E. T., Yao, T., Luc, A. and Danielle, B. (2010). Effects of land use types on soil organic carbon and nitrogen dynamics in midwest Cote d'Ivoire. European Journal of Scientific Research 2: 211-222
[19] Montagnini, F. (2000). Accumulation in above Ground Biomass and Soil Storage of Mineral Nutrients in Pure and Mixed Plantations in Humid Tropical Lowland. Forest, Ecology and Management. 134:257-270.

[20] Narong, K.; Katsutoshi, S. and Sota, T. (2007). Composition and Diversity of Woody Regeneration in a 37-year Old Teak (Tectonal Grandis L.) Plantation in Northern Thailand. Forest, Ecology and Management. 247: 246-254.

[21] Nelson, D. W. and Sommers L. E. (1982). Total carbon, organic carbon and organic matter. In: Page, A. L. et al. (eds). Methods of Soil Analysis. Part 2. Agron. Monogr. 9. Second Edition. pp 539-579. ASA and SSSA. Madison, Wisconsin, U.S.A.

[22] Nwoboshi, L.C. (1970). Studies on Nutrient Cycle in Forest Plantations: Preliminary Observations on Litter Fall and Macro-Nutrient Return in a Teak (Tectona Grandis L.F.) Plantation. Nigerian Journal of Science 4(2): 231-237.

[23] Ojo, A.F. (2005). Organic Matter and Nutrient Dynamics of the Natural Rainforest and Teak Plantation in Akure Forest Reserve, Nigeria. PhD Thesis in the Department of Forestry and Wood Technology, Federal University of Technology, Akure, Nigeria. 130 pp.

[24] Okeke, A.L. and Omaliko, C.P.E. (1992). Leaf Litter Decomposition and Carbon dioxide Evolution in some Agroforestry Fallow Species in Southern Nigeria. Forest, Ecology and Management. 50: 103-116.

[25] Ola Adams, B.A. (1978). Litter fall and Disappearance in a Tropical Moist Semi-deciduous Forest. Nigerian Journal of Forestry 8:31-36.

[26] Onyekwelu, J.C.; Mosandi R., Stimm B. (2006). Productivity, Site Evaluation and State of Nutrition of Gmelina arborea Plantations in Oluwa and Omo Forest Reserve. Nigerian Forest Ecology and Management. 229: 214-227.

[27] Oyeniyi, O.C. and Aweto A.O. (1986). Effects of Teak Planting on Alfisol Topsoil in Southwestern Nigeria. Singapore Journal of Tropical Geography. 7:145-149.

[28] Parrota,J.A. (1992). The Role of Plantation Forests in Rehabilitation Degraded. Tropical Ecosystem, Agricultural Ecosystems and Environment. 41: 115-133.

[29] Parrotta, J .A. (1999). Productivity, Nutrient Cycling, and Succession in Single and Mixed-Species Plantations of Casuarina equietifolia, Eucalyptus robusta and Leucaena leucocephala in Puerto Rico. Forest, Ecology and Management. 124: 47-77.

[30] Rothe A., and Binkley D. (2001). Nutritional Interactions in Mixed Species Forests: A Synthesis, Can. J. Res. 31:1855-1870

[31] Singh, S.B.; Nath, S.; Pal, D.K. and Banarjee (1985). Changes in Soil Properties under Different Plantations of the Darjeeling Forest Division. India Forester 111(2): 90-98.

[32] Sreekala, N.V.; Mercy George, V.K.G.; Unnithan, P.S. and John, R. (2001). Decomposition Dynamics of Cocoa Litter under Humid Tropical Conditions. Journal of Tropical Agriculture. 39: 190-192.

[33] Thomas G. W. (1982). Exchangeeable cations. In: Page A. L. et al. (eds). Methods of soil analysis. Part 2. Agron. Monogr. 9. Second Edition. pp 159- 165. ASA and SSSA. Madison, Wisconsin, U.S.A. 
[34] Tucker, N.I.J. and Murphy, T.M. (1977). The Effects of Ecological Rehabilitation on Vegetation Recruitment: Some Observations from the Wet Tropics of North Queensland. Forest, Ecology and Management. 99: 133-152.

[35] Walkley, A., and Black, I. A., (1934). An Examination of the Degtgareff method for determining soil organic matter and proposed of modification of the chromic acid titration method. Journal of Soil Sciences. 37: 29-33.
[36] Weaner, P.L.; Bindsay, R.A. and Lugo, A.E. (1987). Soil Organic Matter in Secondary Forest in Puerto Rico. Biotropica 19(1): 17-23.

[37] Wood, T.G., (1974). Field investigations on the decomposition of leaves of Eucalyptus delegatensis in relation to environmental factors. Pedobiologia 14, 343-371. 